\title{
Australia chooses spaceport consortium at Queensland site
}

\section{Sydney}

Plans for a private enterprise spaceport on Australia's northernmost tip are winning backers. Last week, the Queensland state government announced that the Cape York Space Agency (CYSA) has been chosen to coordinate efforts to build a full-scale equatorial launch site by 1993 .

A two-year, A\$5 million feasibility study will be the agency's first task. Aubrey Behn, chairman of CYSA, hopes it will end in agreements with both government and private organizations that will permit construction to begin.

Cape York has several advantages: it is near the Equator, where commercial launches are most economical, it is in a country with a stable government, and it has good communications, good weather and, above all, plenty of land. With three

\section{Change for British Civil Service labs \\ London}

RADICAL changes in the organization of the British Civil Service affecting much British civil science are likely to follow from a report of the government's central efficiency unit, published last week. The chief recommendation, which the government has accepted, is that units of the Civil Service providing public services should be regarded as candidates for the status of independent agencies, which in due course would be managed as units separate from the Civil Service proper.

Among the prospects for early formation into agencies are the Meteorological Office and the six non-nuclear research establishments of the Ministry of Defence. But ministers emphasize that the list of putative agencies made public last week is only a first list, and that others will follow.

The objective of the change is more efficient management, to which end the heads of agencies will be allowed a degree of flexibility (still undefined) about questions such as the salaries of those who work for them. But it is intended that agencies will remain responsible to ministers, and subject to financial scrutiny by public and parliamentary auditors, for which reason it is not yet clear how far the proposed changes will affect people's working lives.

While there is no suggestion that units with the status of agencies will eventually be made autonomous as well, their definition will enable the departments from which they spring to regulate more tightly than now the budgetary frameworks in which they operate, which may make for greater comfort or the opposite. years for construction, and an investment of $A \$ 1,500$ million, the first full-scale launch could be in 1993. A further A $\$ 5,000$ million would be needed to build additional launch-pads and support facilities to complete the spaceport in the year 2000 , by which time Behn sees it supporting a township of 40,000 people.

CSYA is a consortium of 64 companies, most of them Australian, but including the Japanese construction company Shimizu Corporation. Companies with significant experience in rocket launching are notably absent from the consortium, although several had joined other groups that had hoped to be chosen to coordinate

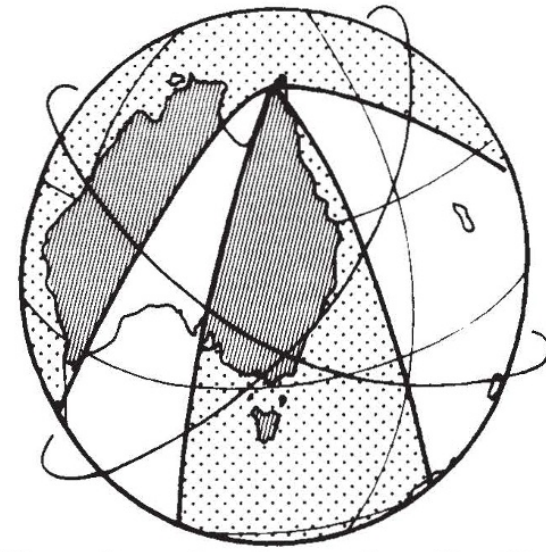

The south-west launch sector from Cape York gives access to polar launches and includes sparsely populated areas around Alice Springs and the old launch site Woomera. To the east and south-east, the sector is over the South Pacific, with New Caledonia 2,500 km down-range.

the project. A proposal by the Australian arm of Sumitomo Corporation, the giant Japanese trading company, to go ahead and build a spaceport was rejected as management and control of the facility would have passed out of Australian hands.

The Queensland government has hedged its bets by giving CYSA only coordinator status and requiring it to bring other companies into the project. The success of the spaceport depends on how well CYSA meets these demands.

The Soviet Union is said to be particularly interested in launching a rocket from Cape York as Australia could make its entry into the commercial satellite launching market more palatable to Western nations. The near-equatorial site would also double the boost their rockets receive from the Earth's spin, permitting a large increase in payload.

Charles Morgan

\section{Correction}

ThE news item "Move to ban sex determination" (Nature 331, 467; 1988) was written by Radhakrishna Rao and Elizabeth Ebbert.

\section{AIDS envelope protein patent}

\section{Washington}

A US PATENT was issued last week to Harvard University for the outer envelope protein of the HIV (human immunodeficiency virus), the virus causing AIDS (acquired immune deficiency syndrome). Myron Essex and Tun-Hou Lee of Harvard are seeking the patent based on their discovery that the gp120 envelope protein reacts strongly with antibodies from blood of people infected with HIV.

The patent contains 10 claims covering gp120 and all proteins that cross-react with it, so most companies involved in the production of AIDS diagnostics, vaccines and possibly even therapeutics will need a licence. Harvard has given exclusive licensing rights to Cambridge BioScience of Worcester, Massachusetts, and representatives of the company say they will sublicense the patent for a fee. Licences will be required only for companies earning profits on products covered by the patent: resarchers studying gp120 will not be required to pay royalties.

Substances that occur naturally are not patentable in their native form, but purified forms of natural substances often are patentable. Such "composition of matter" patents are desirable in biotechnology because patents for products are easier to defend than patents for processes.

In addition to the purified natural form of gp120, the Harvard patent will also cover synthetic and recombinant gp120. The patent could even be interpreted to cover products containing the gp160 protein - the gp120 outer envelope protein plus the gp41 transmembrane portion - if the patent is defined broadly. Antibodies to gp120 and some of the most popular cell lines for producing gp120 are included in the patent.

It is questionable whether the two most widely marketed diagnostic kits for HIV infection - produced by Abbott Laboratories and DuPont - will have to pay royalties under the Harvard patent. Both kits use killed whole-virus proteins linked to an enzyme to detect antibodies raised against any HIV antigen. But many companies are developing kits to detect only antibodies to gp120, because antibodies are thought to form against the gp120 protein very early in infection.

Manufacturers of vaccines against AIDS will be the most likely licensees of the Harvard patent. Genentech and collaborations between Chiron and CibaGeigy, and Repligen and Merck \& Company are developing vaccines based on whole gp120 or gp120 fragments. Cambridge BioScience is developing a gp120 vaccine with Institut Merieux of France. 